\title{
A importância da definição de zonas alvo de treino para o indoor cycling \\ Rui Garganta ${ }^{1}$, Jorge Roig ${ }^{1}$, César Chaves ${ }^{1}$, Ricardo Bomtempo ${ }^{1}$, Nuno Alves ${ }^{1}$ e João Ferreira ${ }^{1}$. \\ ${ }^{1}$ Faculdade de Desporto da Universidade do Porto.
}

Garganta, R.; Roig, J.; Chaves, C.; Bomtempo, R.; Alves, N.; Ferreira, J.;A importância da definição de zonas alvo de treino para o indoor cycling. Motricidade 3(2): 12-13

\section{Introdução}

É do conhecimento geral que as designadas "aulas de grupo" parecem não ter "vocação" para responder às exigências, capacidades e necessidades dos diferentes praticantes. O Indoor Cycle (IC) parece não ser excepção, atendendo a que a intensidade de esforço é, habitualmente, determinada pelo professor em função do ritmo musical (bpm) "imposto" e não em função das capacidades e objectivos dos praticantes.

O problema é que na mesma aula estão utentes de diferentes idades e sexos, com tipos somáticos e níveis de aptidão perfeitamente diferenciados e, como seria de esperar, com objectivos díspares, o que nos leva a pensar que não parece lícito que todas as pessoas sejam sujeitas ao mesmo tipo de intensidade. Pergunta-se, no entanto, o seguinte: será possível, neste tipo de aulas, sugerir uma metodologia capaz de individualizar a carga de treino ou contemplar diferentes objectivos? De facto, enquanto que na maioria das modalidades de grupo a referida individualização se afigura difícil, senão impossível, no IC, tendo em conta que há um professor responsável pelo grupo, que a aula é realizada em ergómetros estacionários e que a monitorização do esforço é relativamente acessível, pensamos que é possível e, porque não, desejável. Apesar disso, podemos constatar que, actualmente, não é comum avaliar a intensidade do esforço e mesmo quando esta é avaliada, por exemplo, com recurso a monitores de Frequência Cardíaca (FC) a monitorização do esforço tem servido apenas para verificar se esta se eleva "임 "muito" ou "pouco" (sem que se tenha bem a 爱 noção do seu significado real). Uma das estra¿̇ tégias para conhecer o seu significado, baseia-se

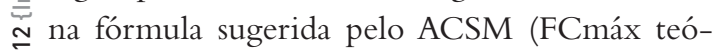

rica $=220$-idade), e na respectiva "zona alvo" para o treino cárdio-vascular (60 a 90\% da FCmáx. teórica). Relativamente à referida estratégia pensamos importante considerar duas limitações: a equação para estimar a FCmáx. contém um erro demasiado grosseiro e apenas existe uma zona alvo de treino. Objectivo desta pesquisa é sugerir um conjunto de zonas alvo de treino que contemple diferentes objectivos.

\section{Metodologia}

10 sujeitos com idades compreendidas entre os 22 e os 35 anos, aparentemente saudáveis, de acordo com o critério do ACSM, realizaram testes maximais de incremento progressivo de carga funcional de minuto a minuto, num total de 10 min. (onde se tinha de atingir o máximo da capacidade de esforço), com o objectivo de determinar o limiar ventilatório e a correspondente FC. Foi ainda registado a sensação subjectiva de esforço (escala de Borg adaptada a 10 níveis) e a capacidade de falar (escala de 5 níveis). Os dados foram recolhidos no Ginásio Status e em bicicletas da marca "Tomahawk". Os limiares ventilatórios foram obtidos com recurso a um oxímetro (Cortex 2000) e as FC foram recolhidas com bandas emissoras e receptor da marca Polar. 


\section{Resultados}

A divisão das zonas alvo são apresentadas de acordo com duas perspectivas: uma mais global, onde se sugerem apenas duas grandes zonas alvo: (1) uma em equilíbrio de esforço (abaixo do limiar), onde a lipólise se sobrepõe à glicólise com um valor estimado em cerca de $85 \%$ da FCmáxE, e outra; (2) cuja continuação do esforço, à mesma intensidade, se torna uma tarefa complicada (acima do limiar), onde a glicólise se sobrepõe à lipólise (acima dos 85 \% da FCmáxE). A segunda perspectiva é mais pormenorizada, baseia-se também na FCmáxE, no entanto sugere 5 zonas alvo (por subdivisão das anteriores), três abaixo e duas acima do limiar. Assim temos: abaixo do limiar: Zona 1: 55 a 65\%; Zona 2: 66 a 75\%; e Zona 3: 76 a 85\% e, acima do limiar: Zona 4: 86 a 95\% e Zona 5: 96 a 100\%. Cada uma destas zonas tem respostas fisiológicas e está associada a diferentes objectivos.

\section{Conclusões}

(1) são cinco as zonas alvo passíveis de ser contempladas em função de diferentes objectivos; (2) a prescrição de treino cárdio-vascular deve considerar a especificidade do esforço.

\section{Correspondência}

Rui Garganta

E-mail: ruigard@fade.up.pt 